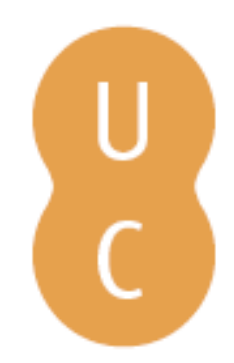

\title{
nommalina
}

\section{SNP-Plex as a complement method in paternity testing}

Autor(es): $\quad$ Dario, P.; Ribeiro, R.; Geada, H.

Publicado por: Imprensa da Universidade de Coimbra; International Academy of Legal

URL

persistente: URI:http://hdl.handle.net/10316.2/31767

DOI: $\quad$ DOI:http://dx.doi.org/10.14195/978-989-26-0173-1_22

Accessed : $\quad$ 26-Apr-2023 10:38:09

A navegação consulta e descarregamento dos títulos inseridos nas Bibliotecas Digitais UC Digitalis, UC Pombalina e UC Impactum, pressupõem a aceitação plena e sem reservas dos Termos e Condições de Uso destas Bibliotecas Digitais, disponíveis em https://digitalis.uc.pt/pt-pt/termos.

Conforme exposto nos referidos Termos e Condições de Uso, o descarregamento de títulos de acesso restrito requer uma licença válida de autorização devendo o utilizador aceder ao(s) documento(s) a partir de um endereço de IP da instituição detentora da supramencionada licença.

Ao utilizador é apenas permitido o descarregamento para uso pessoal, pelo que o emprego do(s) título(s) descarregado(s) para outro fim, designadamente comercial, carece de autorização do respetivo autor ou editor da obra.

Na medida em que todas as obras da UC Digitalis se encontram protegidas pelo Código do Direito de Autor e Direitos Conexos e demais legislação aplicável, toda a cópia, parcial ou total, deste documento, nos casos em que é legalmente admitida, deverá conter ou fazer-se acompanhar por este aviso.

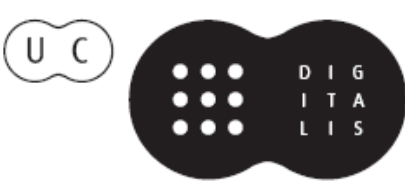




\section{Duarte Nuno Vieira Anthony Busuttil \\ Denis Cusack • Philip Beth}
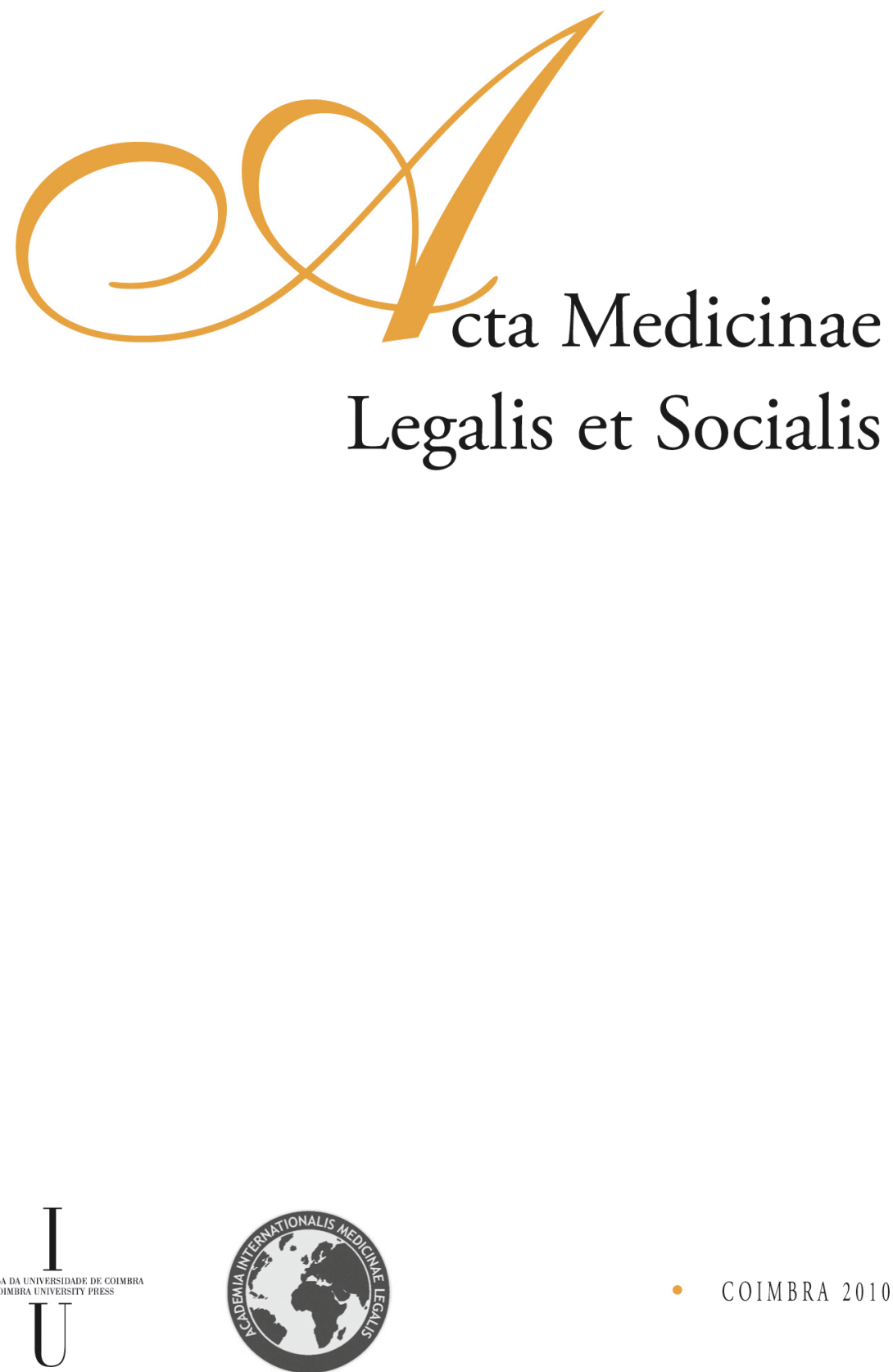
P. Dario ${ }^{1}$, T. Ribeiro ${ }^{1}$, R. Espinheira ${ }^{1}$, H. Geada ${ }^{2}$

${ }^{1}$ Genetics and Forensic Biology Department, South Branch of the National Institute of Legal Medicine, Lisbon, Portugal

${ }^{2}$ Faculty of Medicine, University of Lisbon, Portugal

\title{
20 SNP-PLEX AS A COMPLEMENT METHOD IN PATERNITY TESTING
}

\begin{abstract}
This study intended to examine a set of 20 autosomal Single Nucleotide Polymorphisms (SNPs) selected from the 52-plex developed by the SNPforID Consortium for human identification and to study its usefulness in investigation of paternity cases. We designed two 10-plexes and investigated 50 paternity cases, previously examined in this laboratory with standard STR methodologies. There was a total agreement between exclusion and not exclusion cases with the results obtained by STR analysis, except for one case where it was not possible to exclude the father with SNP analysis, probably due to the small number of SNPs studied. In paternity exclusions, between one and seven incompatibilities were detected for the SNP loci studied. This study demonstrates that analysis of a small number of SNP loci, as 20 polymorphisms, can be very useful in biological kinship investigation as a complement to standard STR methodologies, being an advantage to increase the number of loci to strengthen SNP study as a complement methodology.
\end{abstract}

Keywords: SNPs; paternity testing; SNaPshot.

\section{Introduction}

All over the world, Forensic Geneticists use Short Tandem Repeats (STRs) in the resolution of all kind of cases, being the most important tool in paternity investigation. However, there are cases where STRs usually used in routine analysis are not sufficient for the emission of a report. This is usually derived from the existence of genetic inconsistencies between alleged father and child, derived from meiotic mutation [1] or even from standard technologies used [2], resulting in low paternity indexes and paternity probabilities. In response to this problem, geneticists tend to raise the number, and sometimes the kind, of loci studied in order to raise the confidence of the results obtained, studying a larger number of autosomic STRs, besides X-STRs and Y-STRs whenever possible. Nevertheless, this resource is always subjected to the same problems that originated their use, that is, there could be some genetic inconsistencies between the alleged father and the child in the new loci studied, derived from the relatively high mutation rates of some STRs [3].

In the past years there has been a growing interest in the use of SNPs in several areas of biological sciences, not being exception the field of Forensic Genetics. This is mainly due to the characteristics of these polymorphisms: i) their short amplicon 
sizes, ii) the available high throughput genotyping technologies, and, especially, iii) its very low mutation rate, 100 thousand times lower than the conventionally analyzed polymorphisms, STRs [4]. These characteristics makes SNPs very suitable for genetic identification studies and, therefore, for paternity testing. This study, in continuity of previous work [5], intended to examine a set of 20 autosomal SNPs, selected from the 52-plex developed by Sanchez et. al and the SNPforID Consortium for human identification [6], and to study its usefulness as supplementary markers in investigation of paternity cases, as other authors demonstrated for the complete 52 SNP-Plex $[7,8]$.

\section{Material and Methods}

With the use of SNPforID browser [9], we designed two 10-plexes to analyze a total of 20 SNPs by SNaPshot ${ }^{\circledR}$ methodology (Applied Biosystem). The SNPs chosen from the 52 previously studied by the Consortium were the ones expected to have an allelic frequency closer to 0.5 in the Portuguese population, mainly South-Portugal resident population based on previously studies in the Spanish Galicia population. Loci studied were the following: rs1490413; rs1029047; rs763869; rs735155; rs2107612; rs1454361; rs2111980; rs1005533; rs8037429; rs891700; rs2046361; rs717302; rs1886510; rs729172; rs1024116; rs1463729; rs2076848; rs1355366; rs907100; and, rs737681.

To test the behavior of the selected loci, we investigated 50 paternity cases, with different ethnic-geographical background, previously examined in routine analysis with standard STR methodologies (Promega PowerPlex ${ }^{\circledR} 16$ and Applied Biosystems AmpFlSTR ${ }^{\circledR}$ Identifiler ${ }^{\circledR}$ using the manufacturer instructions). SNP loci were amplified in two 10-plexes using Sanchez et. al [6] conditions. Products of SNP amplification, as STR amplification, were analyzed in 3130/3130xl Genetic Analyzers with GeneMapper® ID Software v3.2 (Applied Biosystems).

\section{Results}

From the analysis of studied cases with SNPs, there was an agreement with the results obtained by STR analysis in exclusion and non-exclusion cases, as can be exemplified in figures 1 to 4 . Figures 1 and 2 show the same paternity with two alleged fathers, where alleged father 2 is excluded from paternity in STR analysis (figure 1) as in SNP study (figure 2). Similarly, figures 3 and 4 illustrate another paternity case, also with two alleged fathers, where alleged father 1 is excluded from paternity in STR analysis but not alleged father 2 (figure 3), the SNP loci showing the same results (figure 4). However, there was one case where it was not possible to exclude the alleged father with SNP analysis. In paternity exclusion cases, between one and seven incompatibilities were detected for the SNPs studied. No mutations were found in this study. 


\section{Discussion and Conclusions}

This study demonstrates that the analysis of as few as 20 SNP loci, with SNaPshot ${ }^{\circledR}$ methodology, can be very useful in biological kinship investigation as a complement to standard STR methodologies. Only in one paternity exclusion case, no genetic incompatibilities were found between the alleged father and the child. This was probably due to the small number of SNPs studied, although this set of SNP loci demonstrated to be very useful. This is true even for cases with different ethnic-geographical background, as is the case in our studied population. However it would be an advantage to increase the number of loci to strengthen SNP study as a complement methodology.

\section{References}

[1] H. GEADA, L. VIRIATO, C. VIEIRA-SILVA, C. CRUZ, I. LUCAS, T. RIBEIRO, R. ESPINHEIRA, STR mutations in paternity investigations: a study of 1-year consecutive cases, International Congress Series, 1239, 2003.

[2] A. AMORIM, C. ALVES, L. PEREIRA, L. GUSMÃO, Genotyping inconsistencies and null alleles using AmpFlSTR ${ }^{\circledR}$ Identifiler ${ }^{\circledR}$ and Powerplex ${ }^{\circledR} 16$ kits, International Congress Series, 1261, 2004.

[3] B. BRINKMANN, M. KLINTSCHAR, F. NEUHUBER, J. HÜHNE, B. ROLF, Mutation Rate in Human Microsatellites: Influence of the Structure and Length of the Tandem Repeat, The American Journal of Human Genetics, 62, 1408-1415, 1998.

[4] J. BUTLER, M. COBLE, P. VALLONE, STRs vs. SNPs: thoughts on the future of forensic DNA testing, Forensic Science, Medicine, and Pathology, 3, 200-205, 2007.

[5] G. COSTA, P. DARIO, I. LUCAS, T. RIBEIRO, R. ESPINHEIRA, H. GEADA, Autosomal SNPs in paternity investigation, Forensic Science International: Genetics Supplement Series, 1, 507-509, 2008.

[6] J. J. SANCHEZ, C. PHILLIPS, C. BORSTING, K. BALOGH, M. BOGUS, M. FONDEVILA, C.D. HARRISON, E. MUSGRAVE-BROWN, A. SALAS, D. SYNDERCOMBE-COURT, P.M. SCHNEIDER, A. CARRACEDO, N. MORLING, A multiplex assay with 52 single nucleotide polymorphisms for human identification, Electrophoresis, 27, 1713-1724, 2006.

[7] C. BORSTING, J.J. SANCHEZ, H.E. HANSEN, A.J. HANSEN, H.Q. BRUUN, N. MORLING, Performance of the SNPforID 52 SNP-plex assay in paternity testing, Forensic Sci Int Genet, 2, 292-300, 2008.

[8] C. PHillips, M. FONDEVIlA, M. GARCIA-MAGARINOS, A. RODRIGUEZ, A. SALAS, A. CARRACEDO, M.V. LAREU, Resolving relationship tests that show ambiguous STR results using autosomal SNPs as supplementary markers, Forensic Sci Int Genet, 2, 198-204, 2008.

[9] J. AMIGO, C. PHILliPS, M. LAREU, A. CARRACEDO, The SNPforID browser: an online tool for query and display of frequency data from the SNPforID project, Int J Legal Med, 122, 435-440, 2008. 


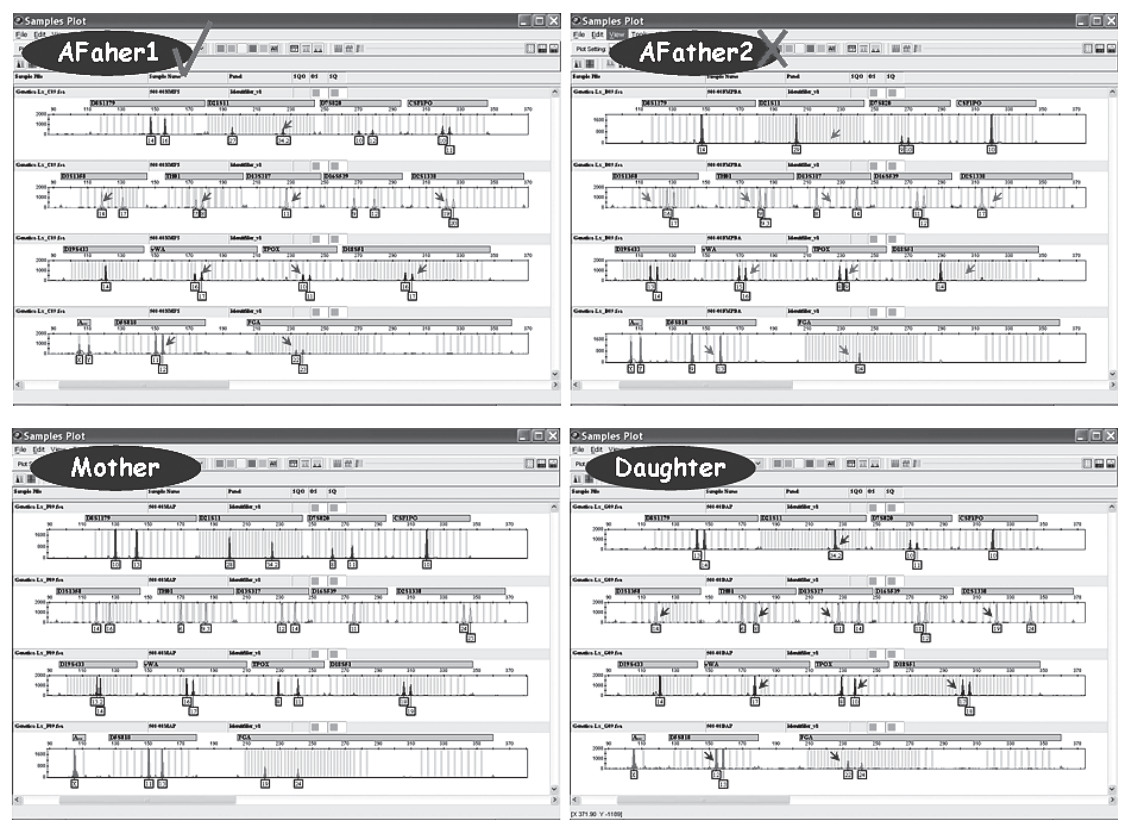

Figure 1 - Case 1 electropherograms (EPG), obtained using Identifiler. It is shown that Alleged Father 1 is not excluded from paternity and Alleged Father 2 is excluded with incompatibilities in 10 STRs.

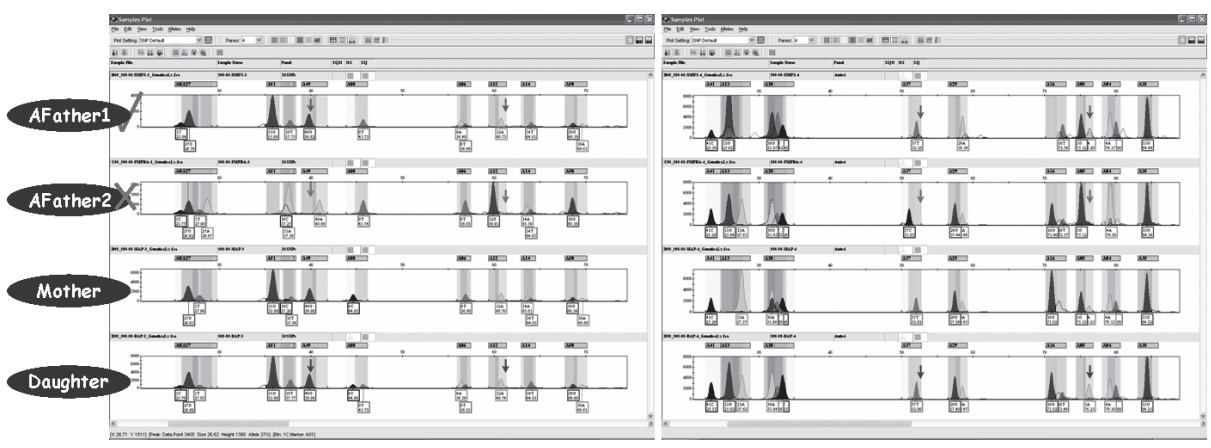

Figure 2 - EPGs obtained with the two 10 SNP-plexes for case 1 . It can be seen that there are 4 incompatibilities with the alleged father 2, also excluded from paternity with STRs. 

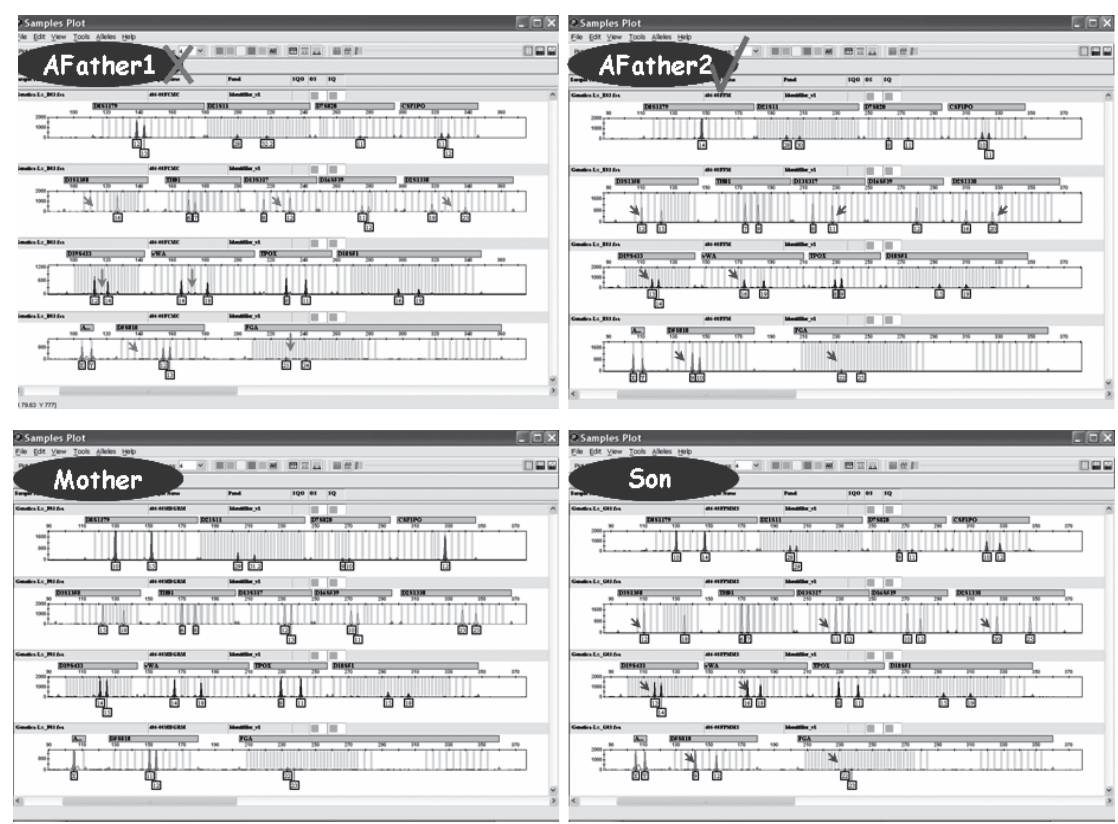

Figure 3 - Case 2 EPGs, obtained using Identifiler. It is shown that Alleged Father 2 is not excluded from paternity and Alleged Father 1 is excluded with incompatibilities in 8 STRs.

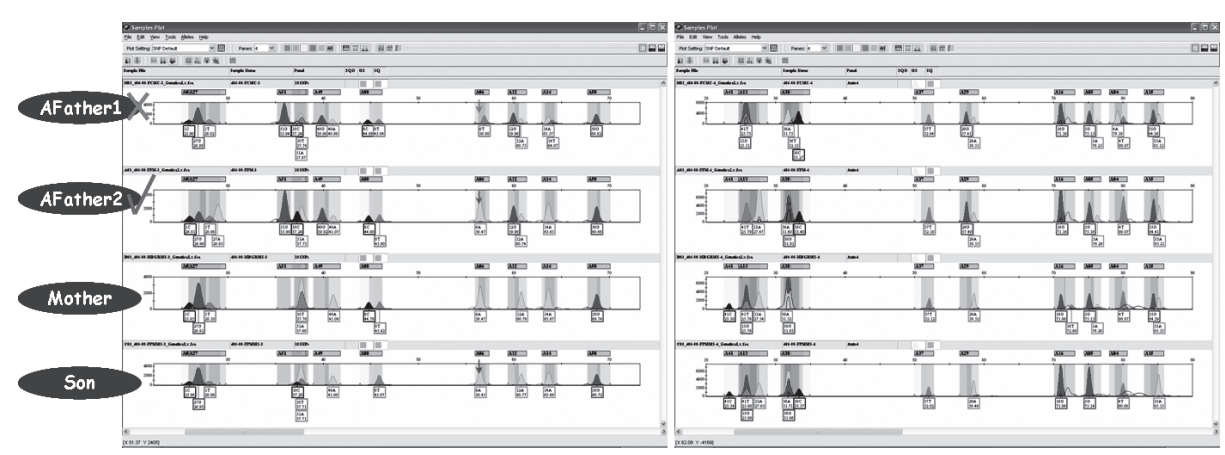

Figure 4 - EPGs obtained with the two 10 SNP-plexes for case 2. It is shown that there is only one incompatibility with Alleged Father 1, excluded from paternity with STRs. 